\title{
Copigmentation of Flavonoids of the Gadung Mango Bark (Mangifera $S p$ ) as a Coloring Substance
}

\author{
Moh. Sahril, *Vanny M. A. Tiwow \& Afadil \\ Program Studi Pendidikan Kimia/FKIP - Universitas Tadulako, Palu - Indonesia 94119 \\ Received 22 September 2021, Revised 15 October 2021, Accepted 17 November 2021 \\ doi: $10.22487 /$ j24775185.2021.v10.i4.pp260-268
}

\begin{abstract}
Flavonoids are pigments in the gadung mango bark that produce a yellow color. The research on copigmentation of flavonoids from gadung mango bark (Mangifera sp) as coloring agents was carried out by the maceration method using 96\% ethanol. The extract obtained was concentrated using a vacuum rotary evaporator at $40^{\circ} \mathrm{C}$. The study aimed to determine levels of flavonoids and stability of color gadung mango bark on the inner and outer of the result copigmentation as a coloring agent. Measurement of total flavonoid levels at a wavelength of $520 \mathrm{~nm}$ and $700 \mathrm{~nm}$ using UV-Vis spectrophotometry. The results of this study indicate that the total flavonoids levels in the inner and outer gadung mango bark samples were $0.162 \mathrm{mg} / \mathrm{g}$ and $0.359 \mathrm{mg} / \mathrm{g}$, respectively. The color stability of flavonoids of the gadung mango bark inside and outside as the results of copigmentation was stable at the temperature $35^{\circ} \mathrm{C}$ and the results obtained in the color stability test of the hero cloth through washing soap water was with a 0 day in 5 hours.
\end{abstract}

Keywords: Gadung mango bark, copigmentation, flavonoids, UV-Vis spectrophotometry

\section{Introduction}

Colorants have long been used in foodstuffs and beverages to improve the appearance of food products. There are two types of dyes, namely natural dyes and synthetic dyes. Natural dyes are dyes obtained from plants and animals. These natural dyes have been used for a long time and are safer than synthetic ones. Still, with the development of science and technology, natural dyes are decreasing in the food industry, which is being replaced by synthetic dyes. That is because synthetic dyes are cheaper and provide more stable colors than natural dyes (Hutapea et al., 2014). Still, apart from having a positive impact, synthetic dyes also have the disadvantage that they contain heavy metals that cannot be degraded/ cannot be damaged, making them one of the factors that cause environmental pollution. For that, a degradable dye is needed to meet the dye needs of the textile industry. Degradable dyes are natural dyes generally found in plants, for example, duwet fruit, grapes, turmeric, mango, and animals (Nugraheni, 2014).

Natural dyes have beautiful and distinctive colors that are difficult to imitate with synthetic dyes, so they are widely preferred; most natural dyes taken from plants are easily degraded. The plant parts used for natural dyes are the bark, twigs, stems, leaves roots, seeds, flowers, and sap. Some natural dyes found around us include chlorophyll, carotenoids, tannins, flavonoids, and anthocyanins (Nugraheni, 2014). Flavonoid, one of the primary pigment groups in plants. One of the flavonoid groups found in plants is mango gadung.

Natural dyes can be obtained from various sources and have multiple chemical structures. Rymbai et al. (2011) stated the three most important natural dyes groups: tetrapyrroles, tetraterpenoids, and flavonoids. Meanwhile, according to Malik et al. (2012), the essential natural pigment groups are; carotenoids, flavonoids, tetrapyrroles, and some xanthophylls as astaxanthin.

One of the natural dyes is a flavonoid, one of the primary pigment groups in plants. One of the flavonoid groups found in plants is mango gadung. According to Ministry of Health (2007), that mango bark contains alkaloids, flavonoids, and tannins. (Gonzalez et al., 2007) suggested that mango peel extract showed antioxidant and antiinflammatory activity.

Flavonoids from the bark of the mango gadung can be used as a source of dye. The bark of the gadung mango has a yellow color. This characteristic of the skin color of the mango gadung stem indicates the presence of flavonoid dyes, but these pigments are easily damaged (Nugraheni, 2014).

\footnotetext{
*Correspondence:

Vanny M. A. Tiwow

e-mail: Vanny.Tiwow@gmail.com

(c) 2021 the Author(s) retain the copyright of this article. This article is published under the terms of the Creative Commons Attribution-NonCommercial-ShareAlike 4.0 International, which permits unrestricted non-commercial use, distribution, and reproduction in any medium, provided the original work is properly cited.
} 
Flavonoid pigments can be damaged easily at high temperatures, and extraction time can affect the rate of flavonoid breakdown (Yuliantari et al., 2017). Therefore the stability of flavonoids needs to be considered. The strength of flavonoids is influenced by temperature, $\mathrm{pH}$, and length of stay. Flavonoids are more stable under acidic conditions and are very reactive to metals to form stable complexes (Nugraheni, 2014); therefore, various technologies to improve the stability of natural dyes in food have been carried out. Copigments are compounds used in copigmentation. Copigment is a colorless compound that is usually found naturally in plant cells. Most studies state that the most commonly used copigments are flavonoids, including flavones, flavanones, and flavanols; besides, phenolic acids and amino acids can also be used as copigments (Santi, 2010). Natural dyes have weaknesses, including unstable colors, poor color uniformity, low pigment concentrations, limited color spectrum (Paryanto et al., 2012).

One of the efforts that can be done to increase the stability of flavonoids is copigmentation. Copigmentation is an interaction between the structure of flavonoids with other molecules such as metals $\left(\mathrm{Al}^{3+}, \mathrm{Fe}^{3+}, \mathrm{Sn}^{2+}, \mathrm{Cu}^{2+}\right)$ and other organic molecules such as flavonoid compounds (flavones, flavonones, flavonols), and so on. The presence of copigmentation between flavonoids and further organic metal molecules increases flavonoids' color stability, produces a lighter color and is protected from oxidation (Boulton, 2001). It can happen because of the interaction between the anthocyanin structure and other molecules called copigment compounds, namely flavonoids (flavones and flavonols) and other polyphenols (phenolic acids), alkaloids (caffeine), amino acids, organic acids, nucleotides, polysaccharides, metals $\left(\mathrm{Al}^{3+}\right)$.

\section{Methods}

The tools used in this study were a dropper, a set of glassware, an Erlenmeyer, a stirring rod, a funnel, a porcelain dish, a digital balance, a cuvette, a test tube rack, a spray bottle, a water bath, a rotaryevaporator, a test tube clamp, and a spectrophotometer. UV-Vis.

The materials used in this study were mango gadung bark obtained from Malala village, Dondo sub-district, Toli-Toli district, $96 \%$ ethanol, $\mathrm{FeCl}_{3}$ solution with various concentrations of $5 \%$ and $10 \%$, buffer solution $\mathrm{pH} 1$ and 4.5, tissue, aluminum foil, Whatman paper no.1.

\section{Sample preparation}

The plant samples used in this study were the inner and outer bark of the mango gadung taken from Malala village, Dondo sub-district, Toli-Toli district. The samples that have been obtained are separated from the outer and inner bark of the mango gadung, then cut into small pieces using a machete. At the same time, the inner skin is sanded using a sanding machine, then blended to facilitate the extraction process.

The mango gadung bark powder on the outside and inside was weighed as much as 150 grams, put into a $1000 \mathrm{~mL}$ Erlenmeyer, then added $600 \mathrm{~mL}$ of $96 \%$ ethanol solvent in a ratio of $1: 4$ until the solvent submerged the entire sample. Covered with aluminum foil, then left for 24 hours and occasionally stirred. The obtained maceration was filtered with Whatman paper no. 1 through a Buchner funnel, and each filtrate was taken. Furthermore, it is concentrated using a rotary vacuum-evaporator at a temperature of $40{ }^{\circ} \mathrm{C}$ (Pasaribu, 2011).

\section{Measurement of total flavonoid level}

Measurement of total flavonoids from the outer and inner bark of the mango gadung stem was carried out using the extracted filtrate. In 2 test tubes, $1.5 \mathrm{~mL}$ of each extract was added. The first test tube was added with $3 \mathrm{~mL}$ of $\mathrm{pH} 1$ buffer solution, and the second test tube was added with 3 $\mathrm{mL}$ of $\mathrm{pH} 4.5$ buffer. Both parts were measured for absorption at wavelengths of 520 and $700 \mathrm{~nm}$ using UV-Vis spectrophotometry, then calculated the absorption and flavonoid content of the sample (Nugrahawati, 2010).

\section{Mordanting}

Mordanting was carried out in this study by cutting 12 pieces of $4 \times 4 \mathrm{~cm}$ cloth. Then soak the fabric in 2 grams of sunlight bar soap in $200 \mathrm{~mL}$ of water for 1 hour. After that, make a solution containing 10 grams of alum $\left(\mathrm{Al}_{2}\left(\mathrm{SO}_{4}\right)_{3}\right)$ and 4 grams of soda ash $\left(\mathrm{Na}_{2} \mathrm{CO}_{3}\right)$ in $200 \mathrm{~mL}$ of water. Then boil the cloth in the solution for 1 hour. The fabric is removed and rinsed with clean water. The fabric is dried and ready to be dyed (Bahri et al., 2017).

\section{Stability test of the outer and inner mango gadung} bark skin color against temperature

A total of $1.5 \mathrm{~mL}$ of the outer and inner flavonoid extracts of the mango gadung bark were put into a test tube and added with $3 \mathrm{~mL}$ of $\mathrm{FeCl}_{3}$ with varying concentrations of $5 \%$ and $10 \%$. Then tested its stability against temperature.

Color stability test against temperature: The above vials were placed in a water bath at a temperature of 35,45 , and $55^{\circ} \mathrm{C}$, then the absorbance was measured at a wavelength of 520 and $700 \mathrm{~nm}$ of extract copigmented with $\mathrm{FeCl}_{3}$ every 60 minutes for a temperature of $35^{\circ} \mathrm{C}, 45$ minutes for $45^{\circ} \mathrm{C}$, and 30 minutes for $55^{\circ} \mathrm{C}$. All measurements were carried out in duplicate (Lestario \& Andini, 2016).

\section{Color stability test on the outer and inner bark of the} mango gadung stem against the fabric

A total of $2.5 \mathrm{~mL}$, then added a solution of $\mathrm{FeCl}_{3}$ fixation with varying concentrations of $5 \%$ and $10 \%$, each as much as $5 \mathrm{~mL}$ into a copigmented test tube and $2.5 \mathrm{~mL}$ of flavonoid extract of the 
outer, inner gadung mango bark extract in an uncopigmented test tube. Silent with variations for 0 days and seven days, the cloth is removed and washed. The concentration of dye remaining in the filtrate was determined by absorbance at a wavelength of $520 \mathrm{~nm}$ and $700 \mathrm{~nm}$ of copigmented and uncopigmented extracts; the absorption was measured using UV-Vis spectrophotometry (Handika, 2002).

Testing the color stability of fabric dyes can be done by washing the dyed material, namely by washing the material with Rinso detergent soap. The value of the color stability test with variations in values of 2 (poor), 3 (good enough), 4 (good), 5 (excellent) (Handika, 2002).

\section{Results and Discussion}

\section{Extraction process}

Extraction is a way to separate a mixture of several substances into components; it is essential to choose a suitable solvent in the extraction process. The extraction method used in this research is maceration. The selection of this extraction method is a method that is simple, easy, and without going through a heating process, so that the possibility of damage to chemical compound components can be minimized, while the purpose of the extraction process is to extract the chemical elements contained in the sample.

The dissolution process was carried out by immersing several samples in a solvent. The samples used in the copigmentation research of the inner and outer bark of the mango gadung stem were used as a coloring agent. The more solvents used in the extraction process, the more compounds extracted (Harborne, 1987). The solvent will penetrate the cell wall and enter the cell cavity containing the active substance. The active substance will dissolve due to the difference in concentration between the active substance solution and outside the cell. Then the concentrated solution is pushed out. This event is repeated until there is a balance between the concentration of the solution outer and inner cell. The solvent used in this study was $96 \%$ ethanol to dissolve flavonoid compounds in the sample. The choice of solvent is because flavonoid compounds are generally in the form of polar glycosides, so they must be dissolved in a polar solvent during the maceration process. The purpose of aluminum foil is so that the ethanol solution in the container does not evaporate, considering the volatile nature of the ethanol. Principle extraction of the mass transfer solute components in a solvent is transferred at the interface layer and diffuses into the solvent (Harborne, 1987). The results obtained concentrated extracts of mango gadung stem as much as $30 \mathrm{~mL}$ inside and $40 \mathrm{~mL}$ outside. Evaporation aims to concentrate the solution by evaporating the solvent from the extract. The solvent evaporation process occurs quickly because of the round bottom flask's rotation. The solvent can evaporate below the solvent's boiling point due to decreased pressure (Agoes, 2007).

\section{Determination of total flavonoid level}

Flavonoids in the outer and inner bark of the mango gadung stem using the differential $\mathrm{pH}$ method. This differential $\mathrm{pH}$ method is used to test the presence of total flavonoids in a sample, so the flavonoid content obtained through this method is assumed to be the entire flavonoid content in the sample. It was done because the basic structure of flavonoid group compounds, namely $\mathrm{C}_{6}-\mathrm{C}_{3}-\mathrm{C}_{6}$, is the basic structure of anthocyanins.

Table 1. Measurement of the total content of the inner and outer bark of the mango gadung stem determines the entire content.

\begin{tabular}{cccc}
\hline \multirow{2}{*}{ No } & Sample & \multicolumn{2}{c}{ Flavonoids in the sample } \\
\cline { 3 - 4 } & Inner skin of gadung mango & 6.746 & $(\mathrm{mg} / \mathrm{g})$ \\
\hline & The outer skin of the gadung mango & 14.962 & 0.162 \\
2 & The & \\
\hline
\end{tabular}

Differential $\mathrm{pH}$ method was used to determine the total flavonoid content in the outer and inner bark of the mango gadung. The added buffer acts as a reagent. $520 \mathrm{~nm}$ is the maximum for cyanidin-3glucoside, and the measurement of the sample at = $700 \mathrm{~nm}$ aims to correct or check the turbidity present in the analyzed solution. (Lee et al., 2005). Flavonoid levels were determined in an acidic environment because acid could denature plant cell membranes and dissolve anthocyanin pigments to leave the cells and prevent flavonoid oxidation. Anthocyanins are a class of flavonoid compounds that function as natural antioxidants; in acidic conditions, anthocyanins are more stable than in alkaline or neutral conditions. Anthocyanins themselves are influenced by several factors, including $\mathrm{pH}$, sugar content, salt content, temperature, and heating time (Aminah et al., 2016).

The extraction results are extraction time, $\mathrm{pH}$, and temperature. The $\mathrm{pH}$ of the extraction solution affects the stability of the pigment color. According to Tensika et al. (2007), it is recommended that flavonoid group compounds be extracted in an acidic environment because the acid functions to denature plant cell membranes, then dissolve the 
anthocyanin pigments they can leave the cells and can prevent flavonoid oxidation. Flavonoids are the largest class of natural phenolic compounds. They are polar compounds because they have several hydroxyl groups, so they are readily soluble in polar solvents such as ethanol and methanol (Arum et al., 2012).

The results are obtained by calculating the flavonoid concentration in the sample solution $(\mathrm{mg} / \mathrm{L})$, which is then converted to dry weight concentration in the sample $(\mathrm{mg} / 100 \mathrm{~g})$. The levels of flavonoids in the inner and outer bark samples of the gadung mango were $0.0162 \mathrm{mg} / \mathrm{g}$ and 0.359 $\mathrm{mg} / \mathrm{g}$, respectively. The results obtained that the highest levels of flavonoids were found in the outer bark of the gadung mango. It shows the lack of flavonoid compounds in the inner bark of the mango gadung compared to the outer skin.

Flavonoids are polyphenolic compounds that function as antibacterial compounds by forming complex compounds against extracellular proteins that interfere with the integrity of bacterial cell membranes.

\section{Mordanting}

The hero cloth to be dyed must be mordanted first. This mordanting process is intended to increase the attractiveness of natural dyes to hero fabrics and helps produce evenness and good color sharpness. Mordanting is the initial treatment of the material to be dyed so that the fat, oil, starch, and dirt left in the dyeing process can be removed; in this process, the fabric is put into a solution of alum and soda ash which will be heated until it boils (Moerdoko, 1975).

According to Scheilin (2009), in dyeing natural dyes in general, mordanting is required on the material to be dyed. The mordanting process is carried out by immersing the material into metal salts as aluminum, iron, tin, and chrome. These mordant substances function to form a chemical bridge between natural dyes and fabric fibers so that the affinity of the dyestuffs increases to the fabric fibers.

Test the color stability of the outer and inner skin color of the mango gadung stem against temperature

Table 2. The results of the analysis of the color stability of the outer bark of the mango gadung stem against temperature

\begin{tabular}{|c|c|c|c|c|c|}
\hline \multirow{2}{*}[\mathrm{FeCl}_{3}]{$(\%)$} & \multirow{2}{*}{$\begin{array}{c}\text { Temperatur } \\
\left({ }^{\circ} \mathrm{C}\right) \\
\end{array}$} & \multirow{2}{*}{$\begin{array}{c}\text { Time } \\
\text { ( minutes) }\end{array}$} & \multicolumn{2}{|c|}{ Absorbance } & \multirow{2}{*}{ Discoloration } \\
\hline & & & 520 & 700 & \\
\hline \multirow{3}{*}{5} & 35 & 60 & 1.108 & 0.682 & \multirow{6}{*}{$\begin{array}{l}\text { It remains black } \\
\text { and forms a } \\
\text { black precipitate }\end{array}$} \\
\hline & 45 & 45 & 0.874 & 0.617 & \\
\hline & 55 & 30 & 0.695 & 0.589 & \\
\hline \multirow{3}{*}{10} & 35 & 60 & 1.149 & 1.035 & \\
\hline & 45 & 45 & 1.020 & 0.833 & \\
\hline & 55 & 30 & 0.827 & 0.558 & \\
\hline
\end{tabular}

Table 3. The results of the analysis of the color stability test of the inner bark of the mango gadung stem against temperature

\begin{tabular}{cccccc}
\hline$\left[\mathrm{FeCl}_{3}\right](\%)$ & $\begin{array}{c}\text { Temperatur } \\
\left({ }^{\circ} \mathrm{C}\right)\end{array}$ & $\begin{array}{c}\text { Time } \\
(\text { minutes })\end{array}$ & \multicolumn{2}{c}{ Absorbance $(\mathrm{nm})$} & Discoloration \\
5 & 35 & 60 & 2.333 & 1.671 & \\
\hline & 45 & 45 & 1.211 & 0.762 & \\
& 55 & 30 & 0.879 & 0.710 & $\begin{array}{c}\text { It remains black } \\
\text { and forms a }\end{array}$ \\
& 35 & 60 & 2.130 & 1.306 & black precipitate \\
& 45 & 45 & 1.620 & 1.061 & \\
\end{tabular}

Based on the results obtained in the stability test of the outer and inner bark color of the mango gadung stem on the effect of temperature, it can be seen in Figures 1-4. 


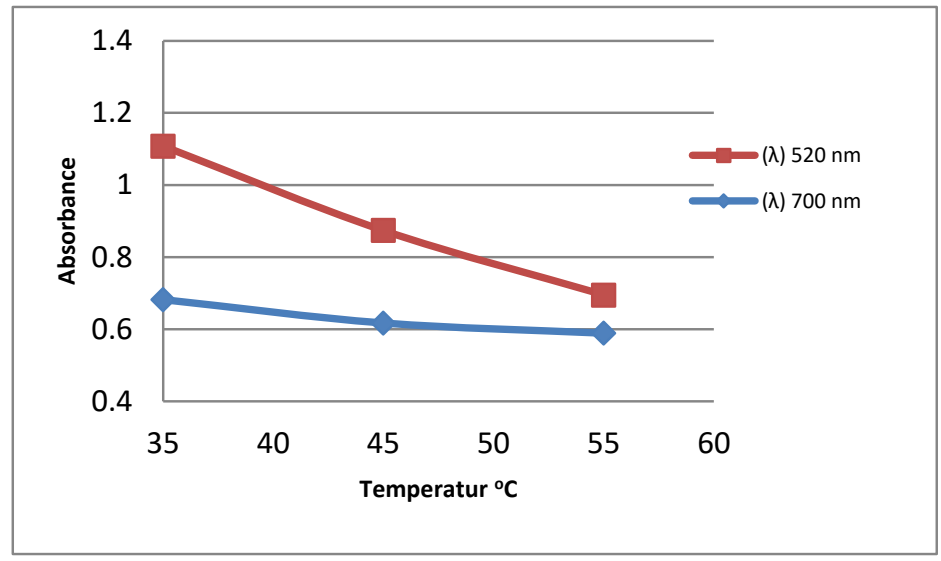

Figure 1. Graph of the relationship of the effect of temperature on the color stability of the outer bark of the mango gadung at a concentration of $5 \%$.

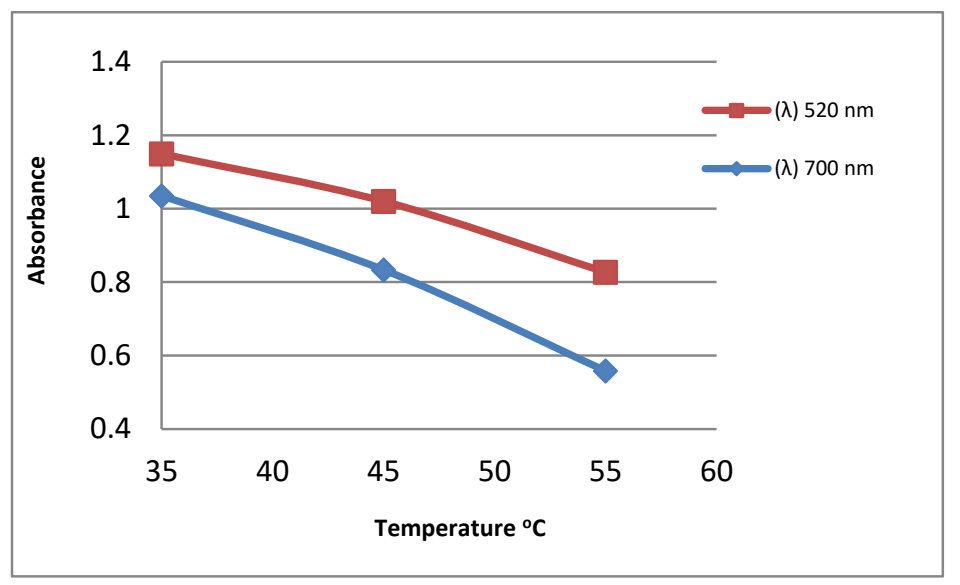

Figure 2. Graph of the relationship of the effect of temperature on the color stability of the outer bark of the mango gadung at a concentration of $10 \%$.

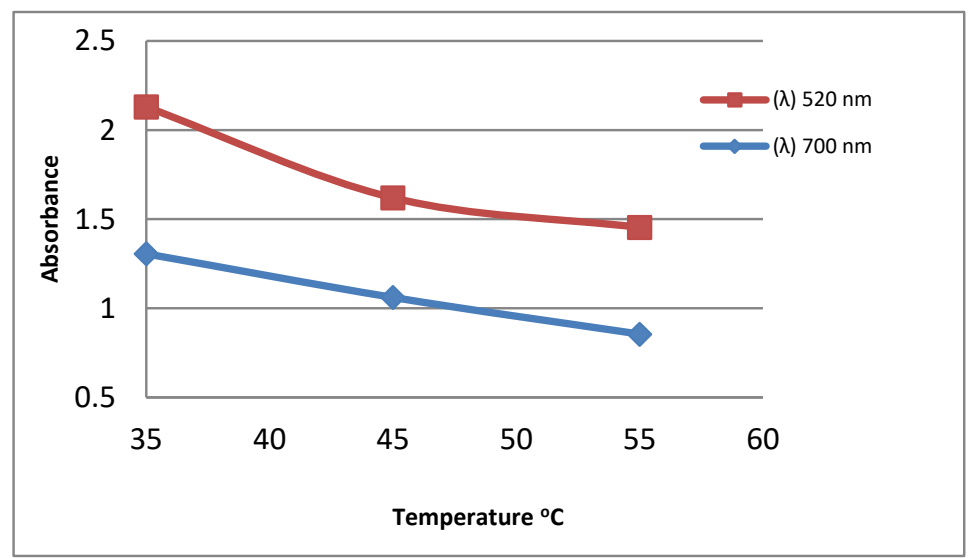

Figure 3. Graph of the effect of temperature on the stability of the color of the inner bark of the mango gadung at a concentration of $5 \%$. 


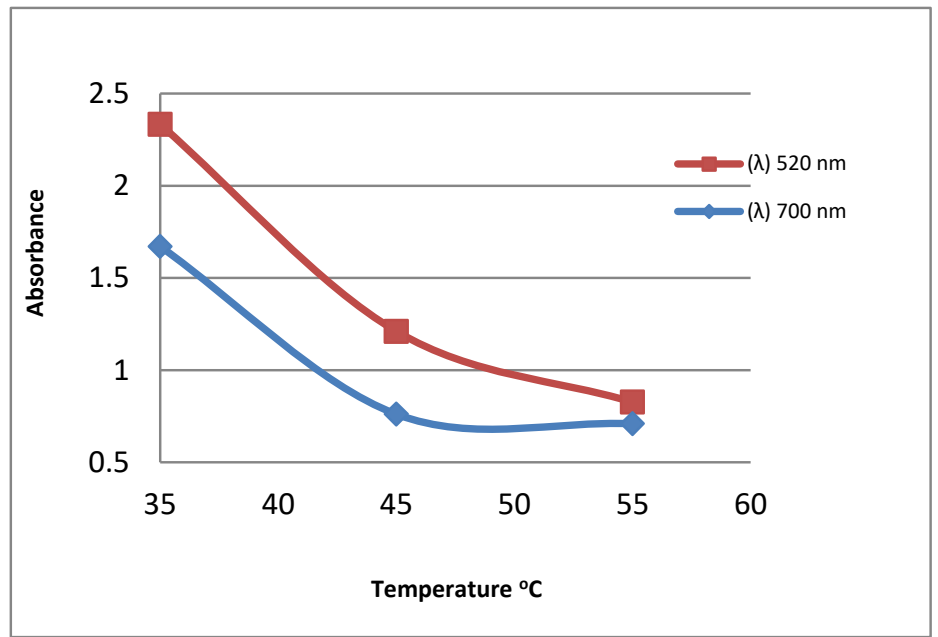

Figure 4. Graph of the relationship of the effect of temperature on the color stability of the outer bark of the mango gadung at a concentration of $10 \%$.

The image obtained shows that the outer and inner extract of the bark of the mango gadung has a dye on the effect of temperature, tested by heating the flavonoid extract, which has been mixed with $\mathrm{FeCl}_{3}$ with variations in concentration, temperature, and heating time. The purpose of using temperatures with different variations is to see the color stability of flavonoid compounds from the outer and inner bark of the mango gadung. The results obtained in the color stability test against the effect of heating are shown in Figures 1-4. It offers that the higher the heating temperature, the lower the absorbance or color stability, during the relationship between absorbance and concentration, the higher the concentration, the absorbance. produced is higher. Sharifi \& Hassani (2012), stated that one of the factors causing the decrease in absorbance value was enzymes. Enzymes cause decolorization of the dye so that the resulting color will fade.
According to Saraswati et al. (2014), at high temperatures, there was a decrease in the stability or discoloration of flavonoid compounds from the outer and inner bark of the mango gadung stem. It can be seen that a higher heating temperature can lower the color intensity. Therefore, the dye intensity is more stable at $35{ }^{\circ} \mathrm{C}$ and has a higher absorbance value than $55^{\circ} \mathrm{C}$. In addition, lower absorbance value affects stability dye on the outside and inside of the mango gadung skin. These conditions show that flavonoid compounds are not resistant to high temperatures above $50{ }^{\circ} \mathrm{C}$, so they undergo structural changes (Ibrahim et al., 2015). According to Garcia-Palazon et al. (2004), low storage temperatures could inactivate enzymes to maintain stability and slow down the degradation of anthocyanins.

Test the color stability of the outer and inner bark of the gadung mango stem against the fabric

Table 4. Data from the color stability test on the outer the bark of the mango gadung stem using Hero cloth

\begin{tabular}{ccccc}
\hline \multirow{2}{*}[\mathrm{FeCl}_{3}]{$(\%)$} & Day & \multicolumn{2}{c}{ Absorbance $(\mathrm{nm})$} & \multirow{2}{*}{ Test Value } \\
\cline { 3 - 4 } & & 520 & 700 & \\
\hline \multirow{2}{*}{ Not Copigmented } & 0 & 2.295 & 1.283 & 3 \\
& 7 & 1.569 & 1.133 & 2 \\
\hline \multirow{2}{*}{5} & 0 & 2.780 & 2.231 & 4 \\
& 7 & 1.860 & 1.070 & $3-4$ \\
\hline \multirow{2}{*}{10} & 0 & 1.730 & 1.242 & 4 \\
& 7 & 1.471 & 0.984 & $3-4$ \\
\hline
\end{tabular}

Description: 2 = not good (cloudy yellow), 3 = good enough (brown yellow), 4 = good (light brown), 5 = very good (dark brown) (Handika, 2002). 
Table 5. Data from the color stability test on the inner bark of the mango gadung using Hero cloth

\begin{tabular}{ccccc}
\hline \multirow{2}{*}[\mathrm{FeCl}_{3}]{$(\%)$} & Day & 520 & 700 & \multirow{2}{*}{ Test Value } \\
\cline { 3 - 4 } & & 1.945 & 1.470 & 3 \\
\hline \multirow{2}{*}{ Not Copigmented } & 0 & 0.756 & 0.625 & 2 \\
\hline \multirow{2}{*}{5} & 7 & 1.272 & 1.034 & 4 \\
& 0 & 0.995 & 0.553 & $3-4$ \\
\hline \multirow{2}{*}{10} & 7 & 1.704 & 1.285 & 4 \\
& 0 & 1.031 & 0.773 & $3-4$ \\
\hline
\end{tabular}

Description: 2 = not good (cloudy yellow), 3 = good enough (brown yellow), $4=\operatorname{good}($ light brown), $5=$ very good (dark brown) (Handika, 2002)

The process of adding $\mathrm{FeCl}_{3}$ fixation solution aims to lock or bind the dye that enters the fabric fiber so that the resulting color does not fade or fade quickly. According to Kwartiningsih et al. (2009), with the addition of metal, there is a strengthening or addition of the penetration power of flavonoids to enter the fabric fiber and hold ionic bonds with the fabric fiber. The cloth from soaking the extract with $\mathrm{FeCl}_{3}$ fixator changes color from the initial color of the white material to black because the flavonoid compounds from the mango gadung bark extract react when mixed with $\mathrm{FeCl}_{3}$ to form complex compounds so that they can change the color, which is flavonoid compounds as ligands with $\mathrm{Fe}$ as atoms center to form tough compounds. The reaction between flavonoids and $\mathrm{FeCl}_{3}$ can be seen in Figure 5.
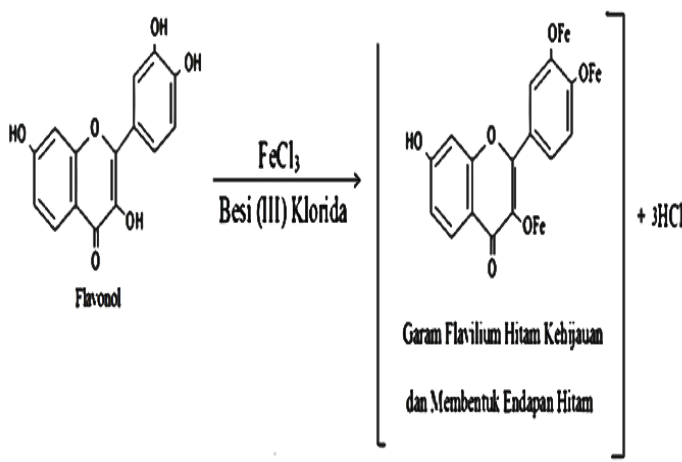

Figure 5. The reaction between flavonoids and $\mathrm{FeCl}_{3}$ metal (Arifin, 1986).

Flavonoids have a hydroxy group as a polar group which in water medium can ionize and make flavonoids slightly reactive. The purpose of using a concentration variation of $5 \%$ and $10 \%$ is to provide color variations that occur in the fabric. The results obtained on the stand with variations 0 days 7 days from the outer and inner bark extract of the mango gadung stem, namely those with a 0 -day stand, the results obtained on fabric fibers are lighter than those with 7 days. The longer the standing process, the more faded the results obtained on the fabric fibers, decreasing the absorbance value. The purpose of the settling process with variations of 0 days and 7 days is to see the color changes that occur in the fabric fibers. The relationship between days and concentration is that the longer the days of residence, the more faded the results obtained. The higher the concentration used, the lighter the color of the fiber obtained.

Testing the stability of the color fastness of the hero fabric through washing with extracts of the inner and outer bark of the mango gadung stem showed good results. Washing aims to test the color stability of the material, this proves that the content contained in the inner and outer bark of the mango gadung stem can be used as a dye with the result of a 0 -day stand that is copigmented with $\mathrm{FeCl}_{3}$. This is caused by flavonoids that bind well to the fabric fiber, with the addition of a $\mathrm{FeCl}_{3}$ color generating agent resulting in increased color fastness stability, due to the inclusion and locking of the dye on the fabric fiber and forming a bond with the fabric fiber and the non-copigmented fabric cannot be used as dye dyes on fabrics, either for 0 days or 7 days because there is no color binding agent that enters 
the fabric fibers. According to (Arifah et al., 2016), the longer the sample storage, will decrease the stability of the natural dye, namely by marking a decrease in absorption (absorbance). It also is due to several factors such as $\mathrm{pH}$, temperature, light, and oxygen. So more stable in the stability of the dye lies in storage at 1 day compared to 7 days which affects the stability of the dye.

\section{Conclusions}

Based on the results obtained in this study, it can be concluded that: The flavonoid levels in the inner and outer bark samples of the mango gadung were $0.162 \mathrm{mg} / \mathrm{g}$ and $0.359 \mathrm{mg} / \mathrm{g}$, respectively. The color stability of the inner and outer skin flavonoids of the copigmented mango gadung as a coloring agent against the temperature in the dyestuff stability is located at a temperature of $35^{\circ} \mathrm{C}$ and the results obtained in the color stability test of hero cloth through washing with soapy water, namely by standing for 0 days for 5 hours

\section{Acknowledgment}

The authors would like to thank the laboratory assistants for Chemistry Education, Faculty of Teacher Training and Education, Tadulako University, laboratory health workers in the Palu area, and those who helped the author complete this research.

\section{References}

Agoes, G. (2007). Teknologi bahan alam. Bandung: ITB Press.

Aminah., Tomayahu, N., \& Abidin, Z. (2016). Penetapan kadar flavonoid total ekstrak etanol kulit buah alpukat (Persea americana mill .) dengan metode spektrofotometri uv-vis. Jurnal Fitofarmaka Indonesia, 4(2), 226-230.

Arifah, C. N., Saleh, C., \& Erwin. (2016). Uji fitokimia dan uji stabilitas zat warna dari ekstrak biji buah alpukat (persea americana mill) dengan metode spektroskopi uv-vis. Jurnal Atomik, 1(1), 18-22.

Arifin, S. (1986). Materi pokok kimia organik bahan alam. Jakarta: Penerbit Kurnia.

Arum, Y. P., Supartono., \& Sudarmin. (2012). Isolasi dan uji antimikroba ekstrak daun kersen (muntingia calabura). Jurnal Matematika dan Ilmu Pengetahuan Alam, 35(2), 165-174.

Bahri, S., Jalaluddin., \& Rosnita. (2017). Pembuatan zat warna alami dari kulit batang jamblang (syzygium cumini) sebagai bahan dasar pewarna tekstil. Jurnal Teknology Kimia Unimal, 6(1), 10-17.

Boulton, R. (2001). The copigmentation of anthocyanins and its role in the color of red wine: A critical review. American Journal of Enology and Viticulture, 52(2), 67-87.

Kwartiningsih, E., Setyawardhani, D. A., Wiyatno, A., \& Triyono, A. (2009). Zat pewarna alami tekstil dari kulit buah manggis. Ekuilibrium, 8(1), 41-47.

Garcia-Palazon, A., Suthanthangjai, W., Kajda, P., $\&$, Zabetakis, I. (2004). The effects of high hydrostatic pressure on $\beta$-glucosidase, peroxidase and polyphenoloxidase in red raspberry (rubus idaeus) and strawberry (fragaria ananassa). Food Chemistry, 88(1), 710.

Gonzalez, J. E., Rodriguez, M. D., Rodeiro, I., Morffi, J., Guerra, E., Leal, F., Garcia, H., Goicochea, E., Guerrero, S., Garrido, G., Delgado, R., \& Nunes-Selles, A. J. (2007). Lack of in vivo embryotoxic and genotoxic activities of orally administered stem bark aqueous extract of Mangifera indica L. (Vimang $\left.{ }^{\circ}\right)$. Food and Chemical Toxicology. 45(12), 2526-2532.

Handika, R. (2002). Ekstraksi zat warna dari daun (acasia auriculuformis) sebagai pewarna tekstil. Unpublished Undergarduate Thesis. Banda Aceh: Universitas Syiah Kuala.

Harborne, J. B. (1987). Phytochemical methods cetakan kedua. Diterjemahkan oleh Padmawinata K. Bandung: Penerbit ITB.

Hutapea, E. R. F., Siahaan, L. O., \& Tambun, R. (2014). Ekstraksi pigmen antosianin dari kulit rambutan (nephelium lappaceum) dengan pelarut metanol. Jurnal Teknik Kimia USU, 3(2), 34-40.

Ibrahim, A. M., Yunianta., \& Sriherfyna, F. H. (2015). Pengaruh suhu dan lama waktu ekstraksi terhadap sifat kimia dan fisik pada pembuatan minuman sari jahe merah dengan kombinasi penambahan madu sebagai pemanis. Jurnal Pangan dan Agroindustri., 3(2), 530 541.

Lee, J., Durst, R. W., \& Wrolstad, R. E. (2005). Determination of total monomeric anthocyanin pigment content of fruit juices, beverages, natural colorants, and wines by the ph differential method: Collaborative study. Journal of AOAC International, 88(5), 12691278.

Lestario, L. N., \& Andini, S. (2016). Kopigmentasi kuersetinapel (pyrus malus) terhadap stabilitas warna ekstrak buah duwet (syzygium cumini). Prosiding Konser Karya Ilmiah Vol 2 (pp 37-42). Salatiga: Universitas Kristen Satya Wacana.

Malik, K., Tokkas, J., \& Goyal, S. (2012). Microbial Pigments: a Review. International Journal of Microbial Resource Technology, 1(4), 361-365.

Moerdoko, W. (1975). Evaluasi tekstil bagian kimia. Bandung: Institut Teknologi Tekstil.

Nugrahawati, Y. A. (2010). Pengaruh berbagai pengaruh variasi subu dan warna kemasan terhadap stabilitas antosianin kulit manggis (gracinia mangostana l.). Unpublished Undergraduate Thesis. Surakarta: Universitas Sebelas Maret. 
Nugraheni, M. (2014). Pewarna alami sumber dan aplikasinya pada makanan dan kesehatan. Yogyakarta: Graha ilmu.

Paryanto, P. A., Kwartiningsih, E., \& Mastuti, E. (2012). Pembuatan zat warna alami dalam bentuk serbuk untuk mendukung industri batik di indonesia. Jurnal Rekayasa Proses, 6(1), 2629.

Pasaribu, M. E. (2011). Isolasi senyawa flavonoida dari kulit batang tumbuhan mangga (mangifera indica l). Unpublished Undergaraduate Thesis. Medan: Universitas Sumatera Utara.

Rymbai, H., Sharma, R. R., \& Srivastav, M. (2011). Bio-colorants and its implications in health and food industry-A review. International Journal of Pharmacological Research, 3(4), 2228-2244.

Santi, W. (2010). Isolasi dan identifikasi senyawa antosianin dari kulit buah anggur (vitis vinifera var. prabu bestari). Unpublished Undegraduate Thesis. Malang: UIN.

Saraswati, N. D., \& Astutik, S. E. (2014). Ekstraksi zat warna alami dari kulit manggis serta uji stabilitasnya. Retrieved May 28, 2019, from Diponegoro University, Faculty of Engineering, Department of Chemical Engineering: http://eprints.undip.ac.id/36701.

Scheilin. (2009). Pengantar kimia zat warna. Bandung: Institut Teknologi Bandung.

Sharifi, A., \& Hassani, B. (2012). Extraction methods and stability of color extracted from barberry pigments. International Journal of AgriScience, 2(4), 320-327.

Tensika., Sukarminah, E., \& Natalia, D. (2007). Ekstraksi pewarna alami dari buah arben (rubus idaeus linn.) dan aplikasi nya pada sistem pangan. Jurnal Teknologi dan Industri Pangan, 18(1), 25-31.

Yuliantari, N. W. A., Widarta, I. W. R., \& Permana, I. D. G. M. (2017). Pengaruh suhu dan waktu ekstraksi terhadap kandungan flavonoid dan aktivitas antioksidan daun sirsak (annona muricata l.) Menggunakan ultrasonik. Scientific Journal of Food Technology, 4(1), 3542. 